\title{
Lichen-Based Nano-Particles, an Emerging Antibacterial Approach
}

\author{
Taswar Ahsan ${ }^{*}$, Liu He ${ }^{2 *}$, Yu Miao², Bingxue Li1", Yuanhua Wu ${ }^{2 \#}$ \\ ${ }^{1}$ College of Land and Environment, Shenyang Agricultural University, Shenyang, China \\ ${ }^{2}$ College of Plant Protection, Shenyang Agricultural University, Shenyang, China \\ Email: taswarahsan@163.com, 2363598334@qq.com, 2363598334@qq.com, "libingxue@syau.edu.cn, "wuyh09@syau.edu.cn
}

How to cite this paper: Ahsan, T., He, L., Miao, Y., Li, B.X. and Wu, Y.H. (2021) Lichen-Based Nano-Particles, an Emerging Antibacterial Approach. Journal of Materials Science and Chemical Engineering, 9, 10-20. https://doi.org/10.4236/msce.2021.98002

Received: July 26, 2021

Accepted: August 14, 2021

Published: August 17, 2021

Copyright ( 2021 by author(s) and Scientific Research Publishing Inc. This work is licensed under the Creative Commons Attribution International License (CC BY 4.0).

http://creativecommons.org/licenses/by/4.0/ (c) (i) Open Access

\begin{abstract}
Bacterial pathogens produced resistance against the existing antimicrobial applications. Scientist trending towards the potent novel eco-friendly and cost effective antimicrobial approaches and fabricating bio-based nano-particles. In this regard, several bio-materials have been investigated, such as, bacteria, fungi, algae, lichens and green plants. Lichens are introduced as an emerging source to synthesis bio-based nano-particles. The lichen-based metal nano-materials, especially fabricated by applying green chemistry strategies, have resulted significant alternates to traditional antimicrobial applications. Several studies break out and revealed that lichen-based nano-particle showed strong antimicrobial efficacy, as the lichens are biologically compatible. Current review summarizes an overview of lichen-based nano-materials, their fabrication, their applications, and their molecular action mechanism. As it emerged a broad spectrum antimicrobial agent for pharmaceutical and agricultural applications.
\end{abstract}

\section{Keywords}

Lichens, Nano-Particles, Antimicrobial

\section{Introduction}

Antibiotic resistance is an ecosystem issue that threatens the health of humans, animals and the environment within the unified framework of "One Health". Resistant bacteria from one geographic area can spread to other parts of the world through direct exposure or through the food chain in a reservoir and environment [1]. However, recent advances in nanotechnology have led to the development of nanoparticles, which are considered effective broad-spectrum an*These authors contributed equally to this work.

${ }^{*}$ Correspondence. 
tibacterial agents [2]. Nanotechnology has been recently revolutionized in the scientific world, especially in the fields of industry, medicine, agriculture, and electronics [3]. The biosynthesis of nanoparticles using green synthesis methods involves the biological reduction of metals or metal element oxides to their basic elements. The shape is from 1 to $100 \mathrm{~nm}$; therefore, the process has received a lot of attention due to its environmental friendliness and cost efficiency [4] [5]. Lichens are extensively studied for the production of green nanoparticles and as well as for the antibacterial efficiency [4]. Basically Lichens are the symbiotic association of fungi and algae. They have several biologically active compounds [6]. Many reports are available on the synthesis of nanoparticles from different types of lichens.

Recently Parmotrema pseudotinctorum and Ramalina hossei were used in combination of two kinds of extracts to synthesize the AgNPs against several grampositive and gram-negative bacteria that caused food poisoning [7]. The four gram-positive pathogens (Bacillus subtilis, Salmonella typhimurium, Staphylococcus epidermidis, and Methicillin-resistant Staphylococcus aureus) and four Gramnegative strains (Salmonella typhi, Proteus vulgaris, Pseudomonas aeruginosa, and Serratia marcescens) were inhibited by using Ag-NP synthesized from water extract of Ramalina dumeticola [8]. NP-Ag produced by four lichens, flounder (Parmeliopsis ambigua), fleshy dots (Punctelia subrudecta), medium-sized Evernia (Evernia mesomorpha) and Xanthoparmelia plitti was tested against various grampositive bacteria, including Pseudomonas aeruginosa, Escherichia coli, Proteus vulgaricus, Staphylococcus aureus, Streptococcus pneumoniae, and Bacillus subtilis and against several gram-negative too [9]. Nano-composites were fabricated by $\mathrm{SiO}_{2}, \mathrm{Fe}_{3} \mathrm{O}_{4}, \mathrm{ZnO}$, and $\mathrm{TiO}_{2}$ by Lecanora muralis against bacterial pathogens (Pseudomonas, Escherichia coli, Staphylococcus aureus) and fungal pathogens (Candida albicans and Candida) [10]. Even anti-mosquito gold nanoparticles were synthesized by using the lichen Parmelia sulcata extract against Anopheles stephensi [11]. Nanoparticles derived from metals and their oxides (such as silver, gold, titanium, cadmium, iron, zinc, and copper) appear to be synthesized using many lichens [12] [13]. Figure 1 shows that, lichen can fabricate NPs with several elements. This article focuses on the usefulness of lichen as a biological laboratory for the sustainable production of antibacterial metal nano-particles.

\section{Analysis and Characterization of Nanoparticles from Lichen}

Calculation of physical characteristics such as stability, crystallinity, charge, dispersion and optical properties is the most important stage in the production of nanoparticles (NPs). To understand this phenomenon, several spectroscopic approaches are required. Functional groups confirmation, charge evaluation and hydrodynamic diameter of NPs, nuclear magnetic resonance spectroscopy, UVvisible spectroscopy, dynamic light scattering, Fourier transform infrared (FTIR), zeta potential are common techniques. Chemical composition, crystal structure 


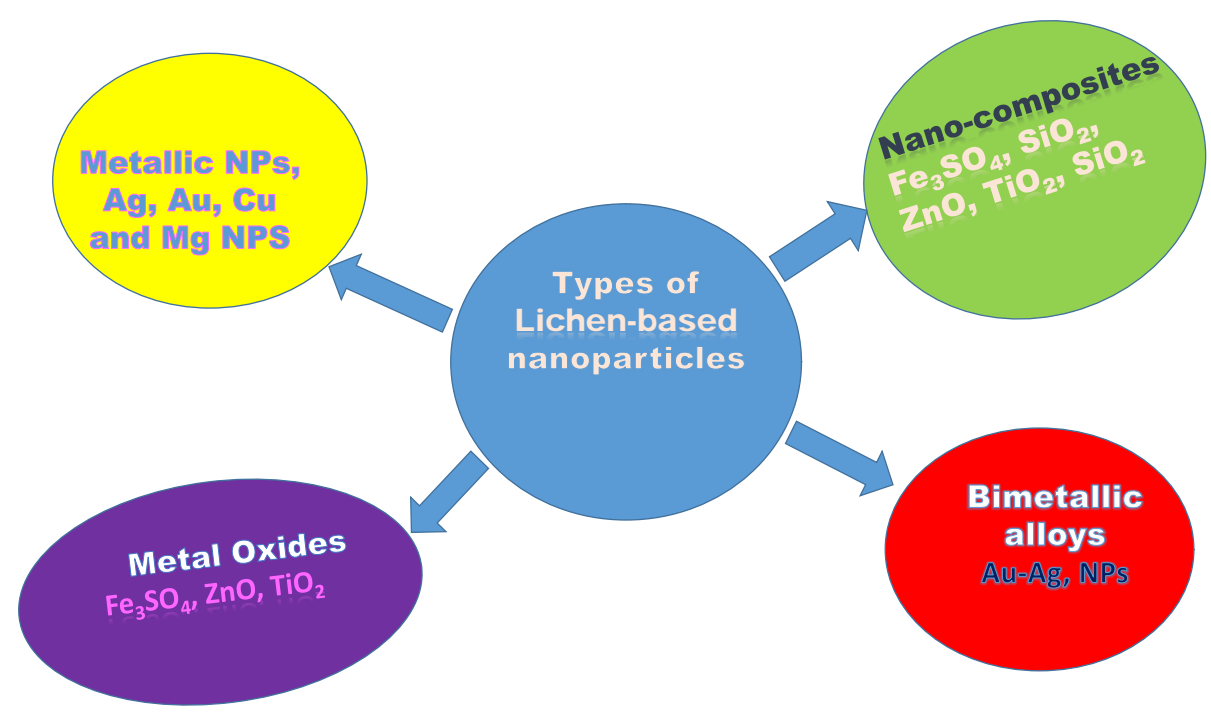

Figure 1. Types of fabricated NPs, by lichen species.

and phase of the fabricated NPs determined by X-ray-based analyses such as $\mathrm{X}$-ray diffraction analysis (XRD), X-ray photoelectron spectroscopy (XPS), and energy-dispersive spectroscopy (EDAX or EDS). Finally Microscopic techniques such as atomic force microscope, Scan electron microscope and Transmission electron microscope is practicing for morphological observation [14]. A schematic representation of analysis described in Figure 2.

Various methods, such as chemical and biomechanical solid-state synthesis, are used to synthesize lichen-based nanoparticles [15]. [4] reported that using the water extract of Parmotrema praesorediosum lichen as a reducing agent and stabilizer to synthesize silver nanoparticles by reducing silver nitrate. Use UVvisible spectroscopy, electron microscopy, energy dispersive spectroscopy (EDS) and X-ray diffraction (XRD) to characterize nanoparticles. The average size of the structured nanoparticles was $19 \mathrm{~nm}$. [16] synthesized magnesium nanoparticles with an average size of $23 \mathrm{~nm}$ from Cladonia rangiferina, and they used light scattering and ultraviolet spectroscopy to characterize the nanoparticles. [8] Successfully synthesized silver nanoparticles by reducing silver nitrate with the water extract of Ramalina dumeticola lichen. The synthesis of silver nanoparticles in solution was confirmed by UV-Vis spectroscopy at $433 \mathrm{~nm}$. Its appearance was characterized by transmission electron microscopy (TEM) and XRD, and it showed a cubic shape with an average size of $13 \mathrm{~nm}$. [17] reported Acroscyphus sp. biosynthesis of gold nanoparticles. They are almost spherical and prismatic in shape, and are characterized by UV-Visible spectroscopy, Fourier transform infrared spectroscopy (FT-IR), powder XRD and TEM. [18] used Cetraria islandica's one-pot method to produce bimetallic nanocomposites with reduced lichen-reduced graphene oxide nanoparticles (LrGO) (LrGO-AgAu). The characterization of nanoparticles, so formed, was carried out using techniques such as TEM, scanning electron microscopy (SEM), XRD, and FT-IR. 


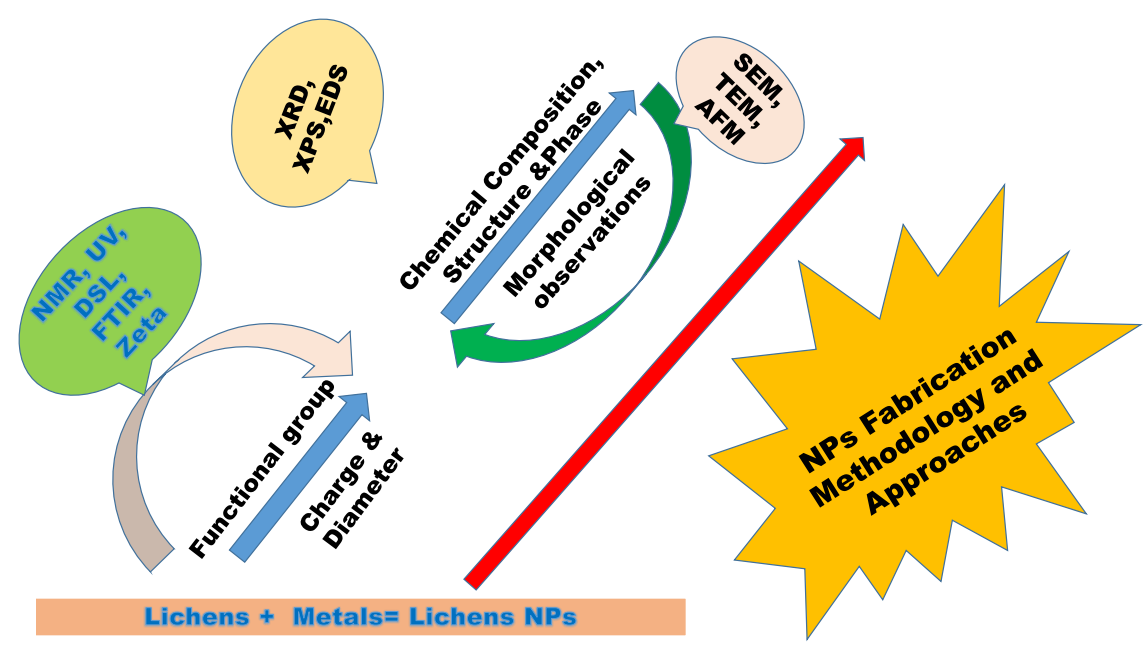

Figure 2. Determination of physiochemical characters. NMR (Nuclear magnetic resonance Spectroscopy), UV (UV-visible spectroscopy), DSL (dynamic light scattering), FTIR (Fourier-transform infrared spectroscopy), zeta potential, XRD (X-ray diffraction), XPS (X-ray photoelectron spectroscopy), EDS (energy-dispersive spectroscopy) AFM (atomic force microscope), SEM (Scan electron microscope) and TEM (Transmission electron microscope).

[15] reported the solid-state mechanochemical synthesis of silver nanoparticles using lichens Xanthoria elegans, C. islandica, Usnea antarctica, and Leptogium puberulum. The method involved milling of lichen sample and silver nitrate together in a pulverisette. The milling process was accompanied by recording of XRD pattern, and after the process of milling was complete, the samples were stored in desiccators, and XRD patterns were recorded. TEM analysis and selected area diffraction (SAD) confirmed the formation of silver nanoparticles. [10] used onepot green synthesis method for the green synthesis of $\mathrm{ZnO} / \mathrm{TiO}_{2} / \mathrm{SiO}_{2}$ and $\mathrm{Fe}_{3} \mathrm{O}_{4} /$ $\mathrm{SiO}_{2}$ nanoparticle composites using the lichen Lecanora muralis. XRD, SEM, EDS, and elemental mapping techniques revealed the fabrication of biosynthesized nanostructure. [19] reported the synthesis of iron oxide nanoparticles from the extract of Ramalina sinensis by co-precipitation method. They confirmed the synthesis of nanoparticles by UV spectrophotometer, XRD, FT-IR, and field emission SEM-energy-dispersive X-ray spectrometry (FESEM-EDX). They reported the synthesis of spherical iron oxide nanoparticles with particle size ranging from 31.74 to $53.91 \mathrm{~nm}$, which were observed using FESEM. The visible UV spectra obtained for the iron oxide nanoparticles showed peak in the range of $280-320$ $\mathrm{nm}$. The nanoparticles exhibited effective antimicrobial properties against Staphylococcus aureus and Pseudomonas aeruginosa. [19] used Pseudevernia furfuracea and Lobaria pulmonaria to synthesize silver nanoparticles with an average size of $10 \mathrm{~nm}$ (while a few reached $100 \mathrm{~nm}$ ) by using solid-state mechanochemical synthesis.

The nanoparticles formed in this way are characterized using methods such as TEM, scanning electron microscopy (SEM), XRD and FT-IR. [15] reported the mechanochemical solid-state synthesis of silver nanoparticles using lichens. Xan- 
thomonas nematodes, $C$. islandica, Usnea antarctica and pubic ept. The procedure involves grinding lichen and silver nitrate samples in a powder grinder. The XRD standard is recorded after the grinding process, and the sample is stored in the desiccator after the grinding process is completed and the XRD standard is recorded. TEM analysis and Selected Area Diffraction (SAD) confirmed the formation of silver nanoparticles. [10] use the green synthesis method to use Lecanora muralis lichen green to synthesize a composite material of $\mathrm{ZnO} / \mathrm{TiO}_{2} / \mathrm{SiO}_{2}$ and $\mathrm{Fe}_{3} \mathrm{O}_{4} / \mathrm{SiO}_{2}$ nanoparticles in a one-pot method. XRD, SEM, EDS and elemental mapping techniques have proven the creation of biosynthetic nanostructures. [19] reported the synthesis of iron oxide nanoparticles from La Marina extract by co-precipitation method, using UV, XRD, FT-IR spectrophotometer and field emission SEM energy dispersive X-ray spectrometer (FESEM-EDX) The synthesis of nanoparticles was confirmed. They reported on the synthesis of spherical iron oxide nanoparticles observed with FESEM, with particle sizes ranging from 31.74 to $53.91 \mathrm{~nm}$. The visible UV spectrum obtained for the iron oxide nanoparticles shows a peak in this range. Nanoparticles have shown effective antibacterial properties against Staphylococcus aureus and Pseudomonas aeruginosa. [19] using solid-state mechanochemical synthesis methods, using pseudomonas pseudomonas and Lobaria pulmonaria to synthesize silver nanoparticles with an average particle size of $10 \mathrm{~nm}$ (some up to $100 \mathrm{~nm}$ ).

\section{Antimicrobial and Antibacterial Behaviour of Bio-Fabricated Lichen Based Nano-Particles}

It is reported that many lichen-based nano-particles have antibacterial biological activity against various bacteria and fungi, which can be explained by their ability to destroy microbial membranes, oxidize various cellular components and generate hydroxyl free [20]. Applications of Lichen based NPs are summarized in Figure 3. [10] studied the antibacterial and antifungal properties of $\mathrm{Fe}_{3} \mathrm{O}_{4} / \mathrm{SiO}_{2}$

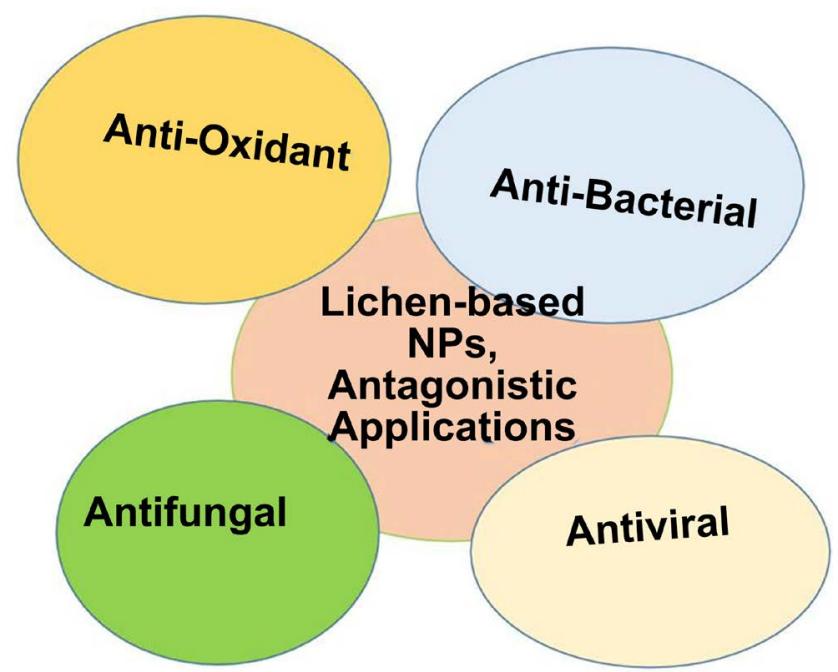

Figure 3. Antimicrobial applications of Lichen-based NPs. 
and $\mathrm{ZnO} / \mathrm{TiO}_{2} / \mathrm{SiO}_{2}$ nanocomposites controlled by Lecanora muralis, and reported that they are effective against three types of pathogenic bacteria (Staphylococcus aureus, Escherichia coli and false Spp.) has good biological activity. And five kinds of fungi (Candida albicans, Candida, Aspergillus flavus, Aspergillus niger and Aspergillus terreus).

Recently, researchers have tried to study and report the antibacterial properties of various types of lichen-based nanoparticles. [4] reported the antibacterial activity of Clostridium pastoris silver nanoparticles against eight bacterial pathogens (including Gram-positive and Gram-negative bacteria). Their results showed that silver nanoparticles synthesized using $P$. praesorediosum have significant antibacterial activity against Gram-negative bacteria. Sidic and so on. [21] reported the antibacterial activity of silver nanoparticles obtained from Usnea longissima against Gram-negative bacteria. Six Gram-positive bacteria (Staphylococcus aureus, Streptococcus mutans, Streptococcus thermos, Streptococcus viridans, Corynebacterium diphtheriae, and Dry bacillus) and three Gram-negative bacteria (Escherichia coli, Cree pneumoniae) Bacteria and Klebsiella pneumoniae. Variant strains, Chlamydia diphtheria and Pseudomonas aeruginosa showed resistance to them. [15] reported that silver nanoparticles obtained from Xanthomonas nematodes, Aspergillus islands, Usnea antarctica and puberty Leptogium puberty are excellent antibacterial agents against E. coli and S. [13]. It was observed that nanoparticles made of metals $(\mathrm{Ag}$ and $\mathrm{Cu})$ and metal oxides $\left(\mathrm{TiO}_{2}\right.$, $\mathrm{ZnO}$ and $\mathrm{Fe}_{3} \mathrm{O}_{4}$ ) controlled by Protoparmeliopsis muralis have antibacterial properties, antibiotic film, antibacterial skin detection and resistance to bacteria and golden yellow Antioxidant properties of Staphylococcus. Escherichia coli and Pseudomonas aeruginosa. There are several antibacterial reports presented in Table 1.

\section{Action Mechanism of Lichen-Based Nano-Particles}

The antimicrobial properties of lichen nanomaterials confirm their ability to disrupt the barrier of microbial cells (cell walls and membranes), enabling them to penetrate the cytoplasm and destroy cell components and genetic material, and ultimately terminate their metabolic functions (Figure 4; [23], however, Compared with 1) interference in the process of cell wall synthesis, 2) cell stress caused by reactive oxygen species (ROS), 3) interference in protein synthesis, and, 4) the proposed possible mechanism for the antibacterial activity of lichen nanoparticles Less. Changes in the transcription process, 5) changes in the main metabolic pathways, 6) introduction of genetic material and 7) changes in cell signaling [24]; however, studies have shown that antibacterial efficacy and the molecular mechanism of lichen nanomaterials depends on 1) the type of material, 2) the shape and size, 3) the composition of the microbial membrane, and 4) the physical and chemical state $(\mathrm{pH}$, temperature, the presence of Co ions, the formation of biofilms, etc.) [25]. [21] demonstrated the antibacterial properties

of silver nanoparticles driven by Usnea longissima by denaturing ribosomes, 
which led to the inactivation of enzymes and proteins, which eventually stopped their metabolic functions and led to bacterial apoptosis. [13] strictly reviewed

Table 1. Lichen-Based NPs and their activity.

\begin{tabular}{|c|c|c|c|c|}
\hline Sr\# & Lichens & NPs & Activity & References \\
\hline 01 & Parmotrema clavuliferum & AgNPs & $\begin{array}{l}\text { Gram-positive bacteria: } \\
\text { 1) Bacillus subtilis } \\
\text { 2) Streptococcus faecalis } \\
\text { 3) Staphylococcus aureus } \\
\text { Gram-negative bacteria: } \\
\text { 1) Pseudomonas aeruginosa }\end{array}$ & [9] \\
\hline 02 & Usnea longissima & AgNPs & $\begin{array}{l}\text { Gram-positive bacteria: } \\
\text { 1) Staphylococcus aureus } \\
\text { 2) Streptococcus mutans } \\
\text { 3) Streptococcus pyrogenes } \\
\text { 4) Streptococcus viridans } \\
\text { 5) Corynebacterium xerosis } \\
\text { 6) Corynebacterium diphtheriae } \\
\text { Gram-negative bacteria: } \\
\text { 1) Escherichia coli } \\
\text { 2) Klebsiella pneumoniae } \\
\text { 3) Pseudomonas aeruginosa }\end{array}$ & {$[21]$} \\
\hline 03 & Protoparmeliopsis muralis & AgNPs Cu NPs & $\begin{array}{l}\text { Gram-positive bacteria: } \\
\text { 1) Staphylococcus aureus } \\
\text { Gram-negative bacteria: } \\
\text { 1) Escherichia coli } \\
\text { 2) Pseudomonas aeruginosa }\end{array}$ & {$[13]$} \\
\hline 04 & $\begin{array}{l}\text { Heterodermia boryi Parmotrema } \\
\text { stuppeum }\end{array}$ & AgNPs & $\begin{array}{l}\text { Gram-positive bacteria: } \\
\text { 1) Staphylococcus aureus } \\
\text { 2) Viridans streptococci } \\
\text { Gram-negative bacteria: } \\
\text { 1) Acinetobacter baumannii } \\
\text { 2) Escherichia coli } \\
\text { 3) Klebsiella pneumoniae } \\
\text { 4) Pseudomonas aeruginosa }\end{array}$ & [22] \\
\hline 05 & Protoparmeliopsis muralis & $\begin{array}{c}\text { CuNPs, } \mathrm{Fe}_{3} \mathrm{NPs} \text {, TiNPs } \\
\text { ZnNPs }\end{array}$ & $\begin{array}{l}\text { Antibacterial, Antibiofifilm, } \\
\text { Antiquorum sensing, Antimotility }\end{array}$ & [13] \\
\hline 06 & $\begin{array}{l}\text { Xanthoria elegans, Cetraria islandica, Usnea } \\
\text { antarctica, and Leptogium puberulum }\end{array}$ & AgNPs & $\begin{array}{l}\text { Gram-positive bacteria: } \\
\text { 1) Staphylococcus aureus } \\
\text { Gram-negative bacteria: } \\
\text { 1) Escherichia coli }\end{array}$ & {$[15]$} \\
\hline 07 & $\begin{array}{l}\text { Pseudevernia furfuracea and Lobaria pul- } \\
\text { monaria }\end{array}$ & AgNPs & $\begin{array}{l}\text { Gram-positive bacteria: } \\
\text { 1) Staphylococcus aureus } \\
\text { 2) Listeria monocytogenes } \\
\text { 3) Bacillus cereus } \\
\text { Gram-negative bacteria: } \\
\text { 1) Escherichia coli } \\
\text { 2) Pseudomonas aeruginosa } \\
\text { 3) Salmonella enterica }\end{array}$ & {$[19]$} \\
\hline 08 & Ramalina sinensis & $\mathrm{FeO}$ NPs & $\begin{array}{l}\text { Gram-positive bacteria: } \\
\text { 1) Staphylococcus aureus } \\
\text { Gram-negative bacteria: } \\
\text { 1) Pseudomonas aeruginosa }\end{array}$ & {$[18]$} \\
\hline
\end{tabular}




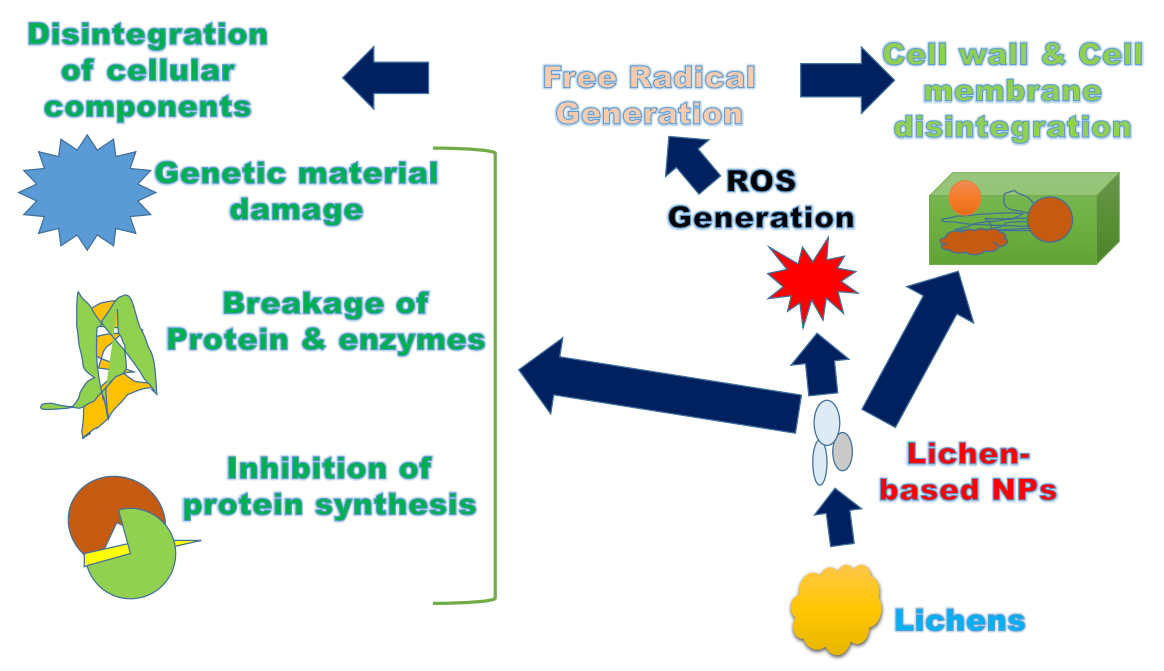

Figure 4. Action mechanism of lichen based NPs against a bacteria.

the green synthesis of Protoparmeliopsis muralis aqueous solution extracted from silver, copper, titanium oxide, zinc oxide and iron oxide nanoparticles and its related antibacterial properties. The total antioxidant capacity (TAC) and 2,2-diphenyl-1-pyridohydrazino hydrate (DPPH) were used to determine the antioxidant properties of the village shrimp. The results clearly show that copper and silver nanoparticles have better antioxidant and antibacterial properties than other nanoparticles.

[9] reported that compared with Klebsiella-positive bacteria, silver nanoparticles based on xanthan skin and flavonoids have greater antibacterial activity against gram-negative bacteria, which may be related to the effect of nanoparticles on gram-negative bacteria. The permeability is stronger than that of Gramnegative bacteria. Gram-positive bacteria are caused by the thinning of the peptidoglycan layer on the cell wall. [18] reported the antibacterial properties of synthetic iron oxide nanoparticles from Chinese Lamarina extract. A study revealed the potential antibacterial effects of synthetic nanoparticles against Gram-positive and Gram-negative bacteria. The electrostatic interaction between the positively charged iron nanomaterials and the negatively charged bacterial cells can cause the bacterial membrane to be oxidized by iron ions and cause oxidative stress in the microbial cells. Cellular components and may cause cell death.

\section{Future Prospective and Conclusion}

According to reports, lichen-mediated nanoparticles are stable, inexpensive and biocompatible, making them ideal candidates for antibiotic use. Due to their unique physical and chemical properties, they can resist a variety of pathogenic microorganisms, such as Gram-positive and Gram-negative. Cost efficiency and cytotoxicity are some of the key issues, which need to be rigorously studied before a comprehensive study of candidate antibiotics in drugs. In addition, there are many obstacles to the biosynthetic process, including toxicity and agglomeration, polydispersity, stability, and inconsistent nanoparticle size. These prob- 
lems can be solved by intensive research to optimize the synthesis of the green woofer and obtain the required woofer. The mechanism of synthesizing NP from natural sources will help the development and adoption of nanomedicine in various fields.

\section{Authors' Contributions}

Conceptualization, T.A.; methodology, T.A, L.B. X and W.Y; software, T.A., L.H., and Y.M.; investigation, T.A. and L.B.X., W.Y.; data curation, T.A., L.B.X., and W.Y; writing-original draft preparation, T.A. and L.B.X.; writing-review and editing, T.A. and L.B.X.; visualization, T.A.; supervision, L.B.X., W.Y.; funding, W.Y. All authors have read and agreed to the published version of the manuscript.

\section{Data Availability Statement}

The data supporting this article are shown in Figures 1-4 and one table. The data sets analyzed in the present study are available from the corresponding author upon reasonable request.

\section{Acknowledgements}

This research was funded by the Dr. Wu Yuanhua, College of Plant Protection, Shenyang Agricultural University, Shenyang, 110866, Liaoning, China.

\section{Conflicts of Interest}

The authors declare no conflict of interest.

\section{References}

[1] Iskandar, K., Molinier, L., Hallit, S., Sartelli, M., Catena, F., Coccolini, F., Craig Hardcastle, T., Roques, C. and Salameh, P. (2020) Drivers of Antibiotic Resistance Transmission in Low- and Middle-Income Countries from a "One Health" PerspectiveA Review. Antibiotics, 9, Article No. 372. https://doi.org/10.3390/antibiotics9070372

[2] Wang, L., Hu, C. and Shao, L. (2017) The Antimicrobial Activity of Nanoparticles: Present Situation and Prospects for the Future. International Journal of Nanomedicine, 12, 1227-1249. https://doi.org/10.2147/IJN.S121956

[3] Saratale, R.G., Karuppusamy, I., Saratale, G.D., Pugazhendhi, A., Kumar, G., Park, Y., Ghodake, G.S., Bharagava, R.N., Banu, J.R. and Shin, H.S. (2018) A Comprehensive Review on Green Nanomaterials Using Biological Systems: Recent Perception and Their Future Applications. Colloids and Surfaces B: Biointerfaces, 170, 20-35. https://doi.org/10.1016/j.colsurfb.2018.05.045

[4] Mie, R., Samsudin, M.W., Din, L.B., Ahmad, A., Ibrahim, N. and Adnan, S.N.A. (2014) Synthesis of Silver Nanoparticles with Antibacterial Activity Using the Lichen Parmotrema praesorediosum. International Journal of Nanomedicine, 9, 121-127. http://doi.org/10.2147/ijn.s52306

[5] Hussain, I., Singh, N., Singh, A., Singh, H. and Singh, S. (2016) Green Synthesis of Nanoparticles and Its Potential Application. Biotechnology Letters, 38, 545-560. 
https://doi.org/10.1007/s10529-015-2026-7

[6] Kambar, Y., Vivek, M., Manasa, M., Vinayaka, K., Mallikarjun, N. and Kekuda, P.T. (2014) Antimicrobial Activity of Leptogium burnetiae, Ramalina hossei, Roccella montagnei and Heterodermia diademata. International Journal of Pharmaceutical and Phytopharmacological Research, 4, 164-168.

[7] Kumar, S.P., Kekuda, T.P., Vinayaka, K. and Yogesh, M. (2010) Synergistic Efficacy of Lichen Extracts and Silver Nanoparticles against Bacteria Causing Food Poisoning. Asian Journal of Research in Chemistry, 3, 67-70.

[8] Din, L.B., Mie, R., Samsudin, M.W., Ahmad, A. and Ibrahim, N. (2015) Biomimetic Synthesis of Silver Nanoparticles Using the Lichen Ramalina dumeticola and the Antibacterial Activity. Malaysian Journal of Analytical Sciences, 19, 369-376.

[9] Alqahtani, M.A., Mohammed, A.E., Daoud, S.I., Alkhalifah, D.H.M. and Albrahim, J.S. (2017) Lichens (Parmotrema clavuliferum) Extracts: Bio-Mediator in Silver Nanoparticles Formation and Antibacterial Potential. Journal of Bionanoscience, 11, 410 415. https://doi.org/10.1166/jbns.2017.1457

[10] Abdullah, S.M., Kolo, K. and Sajadi, S.M. (2020) Greener Pathway toward the Synthesis of Lichen-Based $\mathrm{ZnO@} \mathrm{TiO}_{2} @ \mathrm{SiO}_{2}$ and $\mathrm{Fe}_{3} \mathrm{O}_{4} @ \mathrm{SiO}_{2}$ Nanocomposites and Investigation of Their Biological Activities. Food Science and Nutrition, 8, 4044-4054. https://doi.org/10.1002/fsn3.1661

[11] Gandhi, A.D., Murugan, K., Umamahesh, K., Babujanarthanam, R., Kavitha, P. and Selvi, A. (2019) Lichen Parmelia sulcata Mediated Synthesis of Gold Nanoparticles: An Eco-Friendly Tool against Anopheles stephensi and Aedes aegypti. Environmental Science and Pollution Research, 26, 23886-23898.

https://doi.org/10.1007/s11356-019-05726-6

[12] Çıplak, Z., Gökalp, C., Getiren, B., Yıldız, A. and Yıldız, N. (2018) Catalytic Performance of Ag, Au and Ag-Au Nanoparticles Synthesized by Lichen Extract. Green Processing and Synthesis, 7, 433-440. https://doi.org/10.1515/gps-2017-0074

[13] Alavi, M., Karimi, N. and Valadbeigi, T. (2019) Antibacterial, Antibiofilm, Antiquorum Sensing, Antimotility, and Antioxidant Activities of Green Fabricated Ag, Cu, $\mathrm{TiO}_{2}, \mathrm{ZnO}$, and $\mathrm{Fe}_{3} \mathrm{O}_{4}$ NPs via Protoparmeliopsis muralis Lichen Aqueous Extract against Multi-Drug-Resistant Bacteria. ACS Biomaterials Science and Engineering, 5, 4228-4243. https://doi.org/10.1021/acsbiomaterials.9b00274

[14] Dasari, S., Suresh, K., Rajesh, M., Reddy, S., Samba, C., Hemalatha, C., Wudayagiri, R. and Valluru, L. (2013) Biosynthesis, Characterization, Antibacterial and Antioxidant Activity of Silver Nanoparticles Produced by Lichens. Journal of Bionanoscience, 7, 237-244. https://doi.org/10.1166/jbns.2013.1140

[15] Baláž, M., Goga, M., Hegedus, M., Daneu, N., Kováčová, M.R., Tkáčiková, L., Balážová, L. and Bačkor, M. (2020) Biomechanochemical Solid-State Synthesis of Silver Nanoparticles with Antibacterial Activity Using Lichens. ACS Sustainable Chemistry and Engineering, 8, 13945-13955.

https://doi.org/10.1021/acssuschemeng.0c03211

[16] Devasena, T., Ashok, V., Dey, N. and Francis, A. (2014) Phytosynthesis of Magnesium Nanoparticles Using Lichens. World Journal of Pharmaceutical Research, 3, 46254632.

[17] Debnath, R., Purkayastha, D.D., Hazra, S., Ghosh, N.N., Bhattacharjee, C.R. and Rout, J. (2016) Biogenic Synthesis of Antioxidant, Shape Selective Gold Nanomaterials Mediated by High Altitude Lichens. Materials Letters, 169, 58-61. https://doi.org/10.1016/j.matlet.2016.01.072

[18] Safarkar, R., Rajaei, G.E. and Khalili-Arjagi, S. (2020) The Study of Antibacterial Prop- 
erties of Iron Oxide Nanoparticles Synthesized Using the Extract of Lichen Ramalinasinensis. Asian Journal of Nanosciences and Materials, 3, 157-166.

[19] Goga, M., Baláž, M. and Daneu, N. (2020) Biological Activity of Selected Lichensand Lichen-Based Ag Nanoparticles Prepared by a Green Solid-State Mechano Chemical Approach. Materials Science and Engineering: C, 119, Article ID: 111640.

[20] Marambio-Jones, C. and Hoek, E.M. (2010) A Review of the Antibacterial Effects of Silver Nanomaterials and Potential Implications for Human Health and the Environment. Journal of Nanoparticle Research, 12, 1531-1551. https://doi.org/10.1007/s11051-010-9900-y

[21] Siddiqi, K.S., Rashid, M., Rahman, A., Husen, A. and Rehman, S. (2018) Biogenic Fabrication and Characterization of Silver Nanoparticles Using Aqueous-Ethanolic Extract of Lichen (Usnea longissima) and Their Antimicrobial Activity. Biomaterials Research, 22, Article No. 23. https://doi.org/10.1186/s40824-018-0135-9

[22] Senthil Prabhu, S., Ramanujam, J.R. and Sudha, S. (2019) Antibacterial Activity of Silver Nanoparticles Synthesized by Using Lichens Heterodermia boryi and Parmotrema stuppeum. International Journal of Pharmacy and Biological Sciences, 9, 1397-1402.

[23] Slavin, Y.N., Asnis, J., Häfeli, U.O. and Bach, H. (2017) Metal Nanoparticles: Understanding the Mechanisms behind Antibacterial Activity. Journal of Nanobiotechnolo$g y$, 15, Article No. 65. https://doi.org/10.1186/s12951-017-0308-Z

[24] Vivek, D., Soumya, L., Bharadwaj, S., Chakra, S., Deepika, B. and Sreedhar, B. (2016) Green Synthesis of Silver Nanoparticles Using Coffea arabica Seed Extract and Its Antibacterial Activity. Materials Science and Engineering: C, 58, 36-43. https://doi.org/10.1016/j.msec.2015.08.018

[25] Sánchez-López, E., Gomes, D., Esteruelas, G., Bonilla, L., Lopez-Machado, A.L., Galindo, R., Cano, A., Espina, M., Ettcheto, M. and Camins, A. (2020) Metal-Based Nanoparticles as Antimicrobial Agents: An Overview. Nanomaterials, 10, Article No. 292. https://doi.org/10.3390/nano10020292 